\title{
The occurrence of microscopic algae with blue-green chloroplasts or with endocyanelles (Glaucophyta) in the fresh waters of the Czech Republic, with a new report of Cryptella cyanophora Pascher
}

\author{
Pavel JAVORNICKÝ
}

Lidická 162, 54701 Náchod, Czech Republic; Corresponding authore-mail: pavelavera@gmail.com

\begin{abstract}
One of the observed flagellates, Cryptella cyanophora PASCHER, is probably the first discovery ever of this species with cyanelles after more than 80 years since its description. This species was previously classified into the cryptophycean genus Chroomonas HANSGIRG (see Discussion), which is why the observations of two common species, Chroomonas nordstedtii HANSG. and Ch. caudata GeITLER, from natural water bodies are also presented and the theory of their cytological evolution is discussed. Similar uncertainty is associated with the origin of blue-green chloroplasts of some dinoflagellates, two species of which (from Czech waters) are presented, namely Gymnodinium aeruginosum STEIN and Amphidinium amphidinioides (GeItLer) SchiLler. Again the theory of the origin of their chloroplast is discussed. The indubitable syncyanosis is demonstrated on Glaucocystis nostochinearum ITzigsoHn.
\end{abstract}

Key words: Cryptella cyanophora, Glaucocystis nostochinearum, endocyanelles, Glaucophyta, blue-green plastids in Cryptophyceae and Dinophyceae

\begin{abstract}
Abbreviations for the cell organelles and details in figures: (s) autospores, (ch) chloroplasts, (cv) contractile vacuole, (cy) cyanelles, (es) ejectosomes, (Mc) Maupas corpuscles, (mm) mother membrane of a colony, (nu) cell nucleus, (py) pyrenoid, (rc) red coloured corpuscles, (rm) grains of reserve material, (v) vacuole.
\end{abstract}

\section{INTRODUCTION}

Mereschrowsky (1905) formulated the theory that all chloroplasts were originally procaryotic photosynthetic organisms like Cyanophyta, living in symbiosis with algae and higher plants. He wrote: „Chromatophores... are foreign bodies, foreign organisms, that invaded the colourless plasm of the cell and entered into a symbiotic coexistence with it" (translated by MarTin \& KoWALLIK 1999). PASChER (1929) called these endosymbionts cyanelles and this form of symbiosis syncyanosis. Later it was demonstrated that endocyanelles are covered with peptidoglycan, which is the main element of the cell wall of bacteria including Cyanobacteria. Moreover cyanelles contain exclusively chlorophyll-a which is characteristic for Cyanobacteria.

Current research confirmed that ,plastids first arose by acquisition of photosynthetic prokaryotic endosymbionts by non-photosynthetic eukaryotic hosts.
It is also accepted that photosynthetic eukaryotes were acquired on several accasions as endosymbionts by non-photosynthetic eukaryote hosts to form secondary plastids" (Howe et al. 2008). The photosynthetic prokaryote organisms giving origin to primary chloroplasts were ancestral to present-day cyanobacteria..

Syncyanotic algae were classified into the phyllum Glaucophyta in spite of their seeming origin from different algal groups (Cryptophyta, Chlorophyta). The term Glaucophyta was probably first used by SKUJA (1948) without any definition. That was added later by the same author (SKUJA 1954). The concise characteristics are given by HofFMANN \& Kostikov (2004): „The phyllum Glaucophyta SkUJA (1954) (syn. Glaucocystophyta KIES et KREMER 1986) is a group of eucaryotic algae, lacking chloroplasts and characterised by the presence of blue-greenish organelle-like endosymbionts, termed 'cyanelles' by Pascher." The recent data on phylogeny suggest that Glaucophyta are in fact monophyletic. 


\section{Methods}

The present article does not bring any new evidence of utrastructure, biochemistry, or evolution of Glaucophyta. It just brings attention to some of these organisms, which anyone can observe by optical microscope in fresh water. All algae presented here were observed in live state. Phytoplankton was concentrated by centrifuge with low revolutions but mostly the organisms were sampled and observed together with organic sapropel. Maximum magnification by means of immersed objectives available for the microscopes Zeiss or Meopta was used. Sampling localities are given in the Results.

\section{Results}

The actual record of Cryptella cyanophora PASCHER In the sample of water with phytoplankton from a small village pond in Sedlice near the town Humpolec in southeastern Bohemia, I found very rare, quickly moving flagellates (Figs 1-2). Their cells had the wedge shape typical for Cryptophyceae with a wide apex. The narrowed and pointed antapex was bound towards the cell venter. There was a slightly subapical shallow depression into which two slightly unequal flagella were inserted. A ratively big contractile vacuole moved closely under the cell apex. Most of the cell was filled with a single, massive, slightly irregular sphere of intensive blue-green colour. It looked very much like cyanobacterium. When comparing the size of the blue-green sphere with the size of the colourless flagellate it became clear that this cyanobacterium could not have been swallowed by the protist. The other alternative is that it was a cyanelle. In one cell also the small red corpuscle was placed closely under the surface of the cell venter; it probably was not a stigma. The cells were about $14 \mu \mathrm{m}$ long and $8-8.5 \mu \mathrm{m}$ thick or wide, slightly dorsoventrally flattened.

In spite of certain difference of cell shape, I am sure I found Cryptella cyanophora PASCHER. This might be the first recognition of the species. However, any ejectosomes or nucleus were not visible under the microscope which was at my disposal.

\section{Two Chroomonas species common in the Czech Re- public}

Some of the specimens in question have been published in JAVORNICKÝ (1978). I have never found Chroomonas to form an important proportion of phytoplankton biomass. Chroomonas caudata GeITLER (1924) is less common but well recognizable because of its cell shape (Figs 3-7). The cells of Ch. caudata have the shape of reverse droplet with a wide, obliquely cut apex, and an antapex protruding into the more or less sharply elongated and pointed hyaline cauda. This cauda is distincly curved towards the cell venter. Two unequal flagella are inserted in an apical depression under which are more or less numerous ejectosomes (in a gullet or only alongside the furrow?). A single contractile vacuole is placed apically. The blue-green chloroplast does not fill the entire inner surface of the cell. Its central part adheres to the cell dorsum and protrudes with two lobes along the cell sides. Its ventral slot is rather wide. The conspicuous pyrenoid covered with products of photosynthesis is normally situated at the dorsal part of the chloroplast, but may be shifted to its ventral edge (Fig. 7). The cellls were 9-13 $\mu \mathrm{m}$ long, 4.5-5.5 $\mu \mathrm{m}$ wide and 4-4.5 $\mu \mathrm{m}$ thick, so that they were slightly dorsoventrally flattened. Several small grains of reserve materials were spread in the cytoplasm.

The specimen collected from the small pond near the town Březnice in South Bohemia (Fig. 3) was thin, having long hyaline cauda, rather big pyrenoid and three rows of ejectosomes. Those from the river Vltava in Prague (Figs 4-7) had shorter cauda, relatively smaller pyrenoid, and only 3 ejectosomes.

Chroomonas nordstedtii HANSGIRG (1885) is more common (Figs 8-14). It was found particularly in puddles and shallow ditches with sapropel of ferrous bacteria and overgrown with higher plants, e.g. Equisetum. These minute biotopes were mostly parts of drainage system of fishponds, e.g. of Požár pond at the village Jevany (Figs 9-11) or of the fishponds Pilský (Fig. 8) and Punčocha (Fig. 13) near Mšec - both these localities lie in the general vicinity of Prague. Occasionally the cells of Ch. nordstedtii (Fig. 12) started to multiply in the laboratory tank filled with water from the brook in Prague-Libuš with some addition of sewage (in the experiment carried out by the hydrobiologist J. Justýn).

The cells of $C$. nordstedtii were always thickest in lateral view, oval, with both lines convex, the dorsal line frequently more arched (Figs 8, 11, 12, 13). They were slightly laterally compressed (Fig. 14), 11 - 16 (average 13) $\mu \mathrm{m}$ long, 5-5.8 (av. 5.5) $\mu \mathrm{m}$ wide (side/side) , 6.5-8.5 (av. 7.5) $\mu \mathrm{m}$ thick (dorsum/venter). The dorsal part of the apex protruded in the rounded rostrum which contained a relatively large single contractile vacuole. On the ventral side of the apex there was a shallow notch into which led the short gullet inlaid with several tiny ejectosomes. Two slightly uneven flagella, shorter than the cell length, were inserted in the mouth of the gullet. Most of the inner surface of the cell body was covered with the single bright bluegreen chloroplast. Small or rather sizable (Figs 9 and 12) colourless corpuscles of assimilates were spread in cytoplasm.

The orientation of the cells of Ch. nordstedtii is determined by the dorsal position of the apical rostrum containing the contractile vacuole, and the subapical notch situated on the ventral side of the rostrum, into

Figs 1-7. (1-2) Cryptella cyanophora PASCHER: (1) lateral view, (2) dorsal view; (3-7) Chroomonas caudata GeITLER: $(3,4,7)$ lateral views, (5) apical view from equatorial level down, (6) ventral view. 


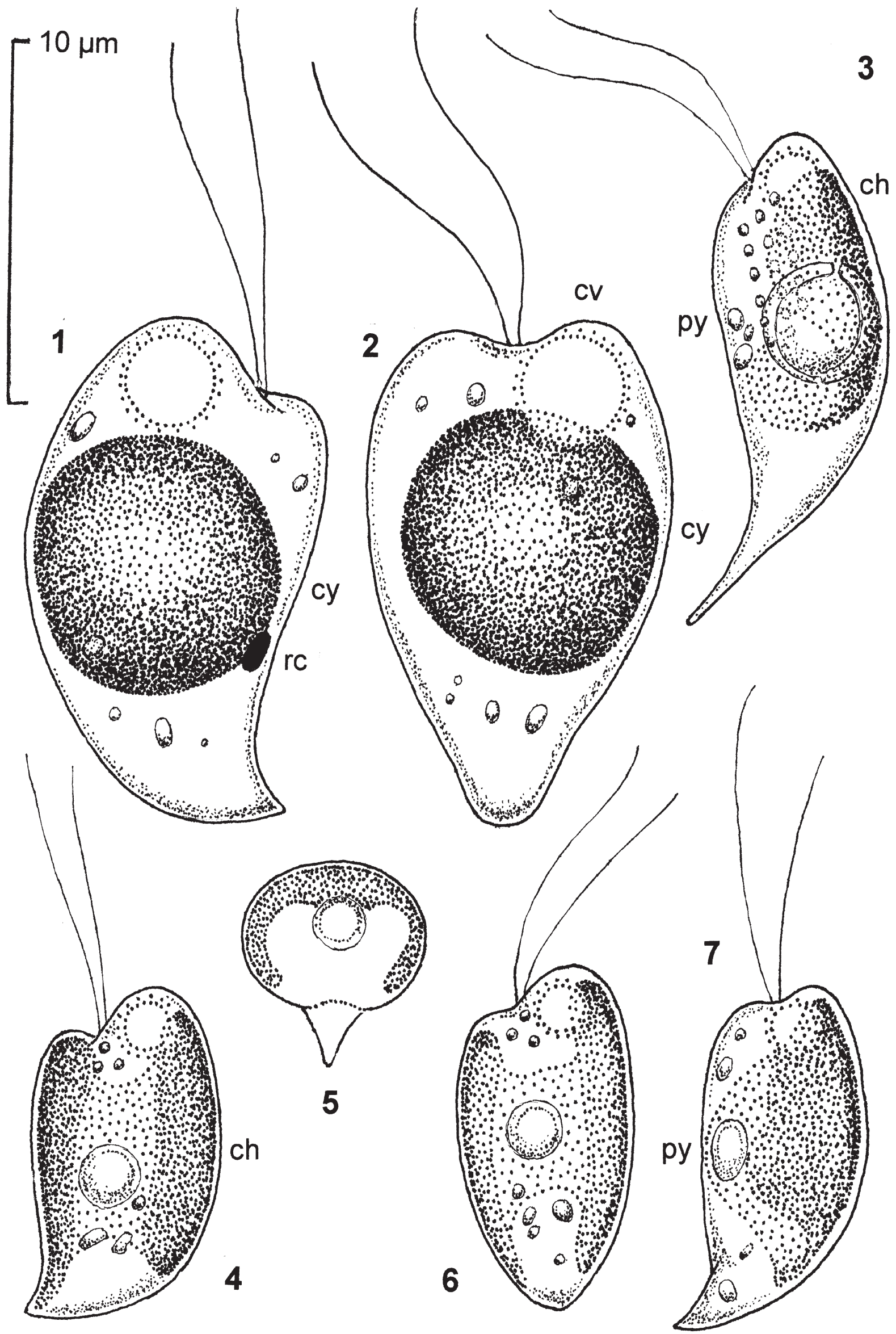


which flagella are inserted, Usually the cell dorsum is more convex than the venter. The arrangement of the infracellular organelles is rather chaotic. The slot between the lobes of the chloroplast is undulated and sometimes visible from the side (Fig. 8a). The pyrenoid often adheres to the ventral lobe of the chloroplast and the position of two or three corpuscles of Maupas seems to be arbitrary. The occurence of two chloroplasts and pyrenoids (Fig. 10) is probably the state preceding cell division.

\section{Two dinoflagellates with blue-green endosymbiont common in the Czech Republic}

Some observances of these dinoflagellates have been published in JAVORNICKÝ (1978). Cells of Gymnodinium aeruginosum STEIN (Figs 15-18) are ovoid, the epicone is a bit shorter than the hypocone (proportion $1: 1.2-1.4)$ and the upper cell part has the shape of vaulted cone with a blunt apex. The slightly dorsoventrally flattened cells (Fig 15b) in my samples were 2636 (average 30.4) $\mu \mathrm{m}$ long, 19- 27 (av. 23) $\mu \mathrm{m}$ wide (side/side), 12-18 (av. 14.4) $\mu \mathrm{m}$ thick (dorsum/venter). The transverse furrow (cingulum) is relatively deep and wide and both ends meet on cell venter without any shift - the cingulum does not have a spiral course. The longitudinal furrow (sulcus) is usually narow, reaching the antapex, where it makes the shallow notch on some specimens. Into epicone the sulcus runs out with a tooth-like notch (Figs 15a and 17). Two flagella are placed in the furrows, inserted in the centre of cell venter, the longitudinal one being longer than the cell. Numerous bright blue-green chloroplasts have the form of little irregular discs or radially composed worm-like rods (compare Fig. 15 with 17-8). Chloroplasts in some specimens are closely clustered, thus forming an almost compact mass (Fig. 16). No stigma or red droplets were observed. A big spherical nucleus with a pearl-like structure is located in the epicone.

The species is common although not abundant in fishponds with Sphagnum littorals like the Řežabinec pond in southern Bohemia (Fig. 16) or the Padrt' pond in western Bohemia (Fig. 15). I also foud samples of it together with Chroomonas nordstedtii in pools with sapropel and higher plants (Equisetum) in the littoral of the Punčocha fishpond at Mšec, in the vicinity of Prague (Figs 17-18).

Amphidinium amphidinioides (GeITLER) SCHILLER (Figs 19-21): The barrel-shaped cells possess a very small epicone: its proportion to the hypocone is $1: 2.5-3.5$. The cells in my samples were $21.6-28$ (average 24) $\mu \mathrm{m}$ long, 18-18.7 (av. 18.2) $\mu \mathrm{m}$ wide and about $14 \mu \mathrm{m}$ thick, i.e. they are slightly dorsoventrally flattened (Fig. 19b). Both cell poles are broadly rounded. Transverse furrow (cingulum) is deep, relatively wide and circular, without any spiral shift. The longitudinal furrow (sulcus) is narrow and does not reach the antapex. The sulcus extends beyond the edge of the flat epicone by a small portion. Numerous bright blue- green chloroplasts have the shape of relatively large irregular plates. In every cell there was one (occasionally two) small red corpuscle, pale or intensive red - a stigma or a droplet of coloured oil substance? If the large spherical nucleus with a pearl-like structure was apparent, it was located in the hypocone (Fig. 21). Tiny colourless grains of reserve material were spread in the cytoplasm.

Amphidinium amphidinioides was sampled with sapropel from shallow peat-bog drain close to the village of Mažice in southern Bohemia (Figs 19-20), and in the muddy littoral of the fishpond Punčocha close to Mšec in the vicinity of Prague, together with $C h$. nordstedtii and G. aeruginosum (Fig. 21).

\section{Glaucocystis nostochinearum ITZIGSOHN}

I found a rich population of this alga in the small fishpond with sphagnetum close to one side of it, most of its shore being surrounded by a forest. It lies about 1 $\mathrm{km}$ from the small settlement of Kaproun (Kaltbrunn in German) in the vicinity of Nová Bystrice, in the southern part of the Českomoravská vysočina (CzechMoravian Highland) (Figs 22-32 ). Its solitary cells or groups of autospores, inside the mother membrane, were settled among the epiphytic (on Potamogeton lucens) and epipelic (growing on mud) algae: Oedogonium, Mougeotia, Tabellaria, Anabaenopsis, Stylopyxis etc. Occasionally, Glaucocystis clung to the filament of Oedogonium (Fig. 26).

The outer habitus of Glaucocystis is the same as of the chloroccocal alga Oocystis. Young solitary cells are of oval shape with a rather thick cell wall without any perceptible thickenings (Figs 22, 25, 28, 31). The wall of some cells starts to thicken on cell poles (Fig 27). These polar thickenings become outstanding on the poles of the big cells containing autospores (colonies) (Figs 23, 24, 29), and rarely, only one cell pole is thickened (Fig. 32). After some time the wall of a colony cracks, thus releasing the autospores (Fig. 30). The innner structure of Glaucocystis differs from that of Oocystis. There are no chloroplasts but conspicuos blue-green elongated corpuscles - indubitable cyanelles. They are elongated, vermiform twisted, mostly club-shaped with distant ends thicker. In mature cells cyanelles are radially composed by slender ends around the lucid central space covered with minute granula; it is evidently a vacuole. In this way cyanelles make fan-like formations, normally one in every cell. Their composition may by chaotic in autospores or in young cells (Fig. 28). Uncommonly there are two „fans" of cyanelles in one cell, which is probably the first phase of cell division (Fig. 26). A few colourless grains scattered in cytoplasm are probably products of photosynthesis.

Figs 8-14. Chroomonas nordstedtii HANSGIRG: (8a) lateral view, (8b) ventral view of the same specimen, (9-13) lateral views, (14) contour of the equatorial cell level. 


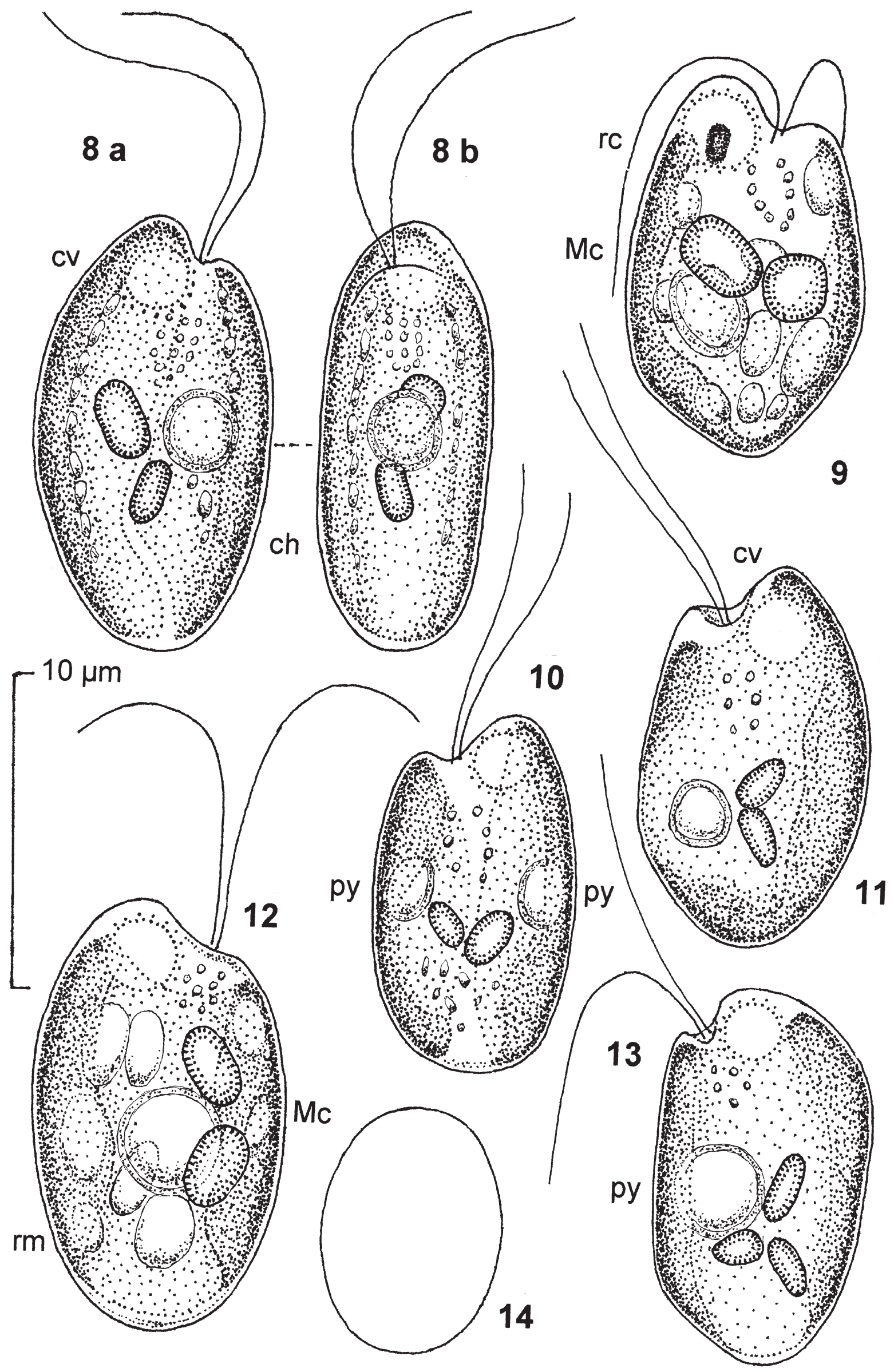


The solitary cells in my material were 20.5-22 (average 21.2) $\mu \mathrm{m}$ long and 9.5-13.5 (av. 11.3) $\mu \mathrm{m}$ wide. The colonies were 29-36 (av. 31.8) $\mu \mathrm{m}$ long and 22-30 (av. 24.8) $\mu \mathrm{m}$ wide. The autospores (cells within colonies) were 15-20.5 (av. 17.4) $\mu \mathrm{m}$ long and 8.3-12 (av. 9.6) $\mu \mathrm{m}$ wide. The cyanelles were about $5 \mu \mathrm{m}$ long and 1.3 $\mu \mathrm{m}$ wide.

\section{Discussion}

\section{Cryptomonad-like flagellates with endocyanelles}

The first discovered species of this group was Cryptoglena americana B. M. DAVIS (1894), renamed later on Cyanomonas americana (B. M. DAvis) Oltmanns (1904). Originally it was collected from salt marshes in Massachusetts, USA, but later it was detected in freshwaters and several new species have been described. In the present time it is cultivated and the nukleotide sequence was published by Moran (2003). Originally Cyanomonas was recognized as a distinct genus belonging to the class Cryptophyceae. Cyanomonas possesses several (up to 10) discoid blue-green plastids which are supposed to be endocyanelles.

KorshiKov (1924) described the new genus with two species: Cyanophora paradoxa, the freshwater flagellate with two spherical cyanelles, and $C y$ anophora tetracyanea with strongly dorsoventrally flattened cells, each containig four cyanelles. C. tetracyanea was later recognized by SKUJA (1956, p. 353). PASCHER (1929: p. 408) wrote about this genus: „Es ist nicht mit sicherheit zu behaupten, dass hier ein sicherer Fall von Endosyncyanose vorliegt." However, $C$. paradoxa was later cultivated and has undergone an investigation by modern methods. The research on Cyanophora paradoxa is summarized by FogG et al. (1973). It was found that endosymbionts in the flagellates are surrounded intracellularly by a thin limiting membrane only, in contrast to free living Cyanobacteria. The chromatoplasm of cyanelles shows the typice lamellar arrangement found in Cyanobacteria. MüLLER et al. (1997) ascertained that cyanelles in Cyanophora paradoxa contain the set of pigments characteristic for Cyanobacteria, namely chrophyll-a, phycobiliproteins (phycocyanin), and carotenoids. Phycobiliproteins serve as storage material of assimilated carbon, instead of starch in green algae. Moreover R. E. LEE (2008) discovered that in Cyanophora paradoxa, ,nitrogen fixation occurs alongside the primary function of photosynthesis“. This is another evidence that Cyanobacteria are present.

Playfair (1925) described the species Cryptomonas gemma containing two „chromatophores“, probably cyanelles. Huber-Pestalozzi (1950, s. 36) mentions it as the ,uncertain species" Chroomonas gemma (PlAYFAIR) PASCHER. On the other hand, PASCHER (1929: 409) wrote: „Chroomonas gemma...ebenfalls einen weiteren Fall von Endocyanose darstellt." Playfair's species is most probably identical with Cyanophora paradoxa KoRSHIKOV.

Pascher (1929) described two new genera and species of colourless flagellates containing endocyanelles, namely Cryptella cyanophora and Peliaina cyanea. The morfology of their cells, two unequally long flagella, apical contractile vacuole, ventral ejectosomes (Cryptella), and nucleus with nucleolus in antapex correspond to Cryptophyceae. Nevertheless PAscheR (1929) did not assume any phylogenetic relationships between these genera and cryptomonads, and supposed that the morphological similarities are the result of evolutionary convergence (NovARINO 2003). Both genera were collected by Pascher in Czech and Austrian peatbog puddles and probably have not been recognized by any researchers since that time. Therefore no ultrastructural or molecular information is available.

The most recent works have been interpreted so that primary plastids indicate the monophyletic origin of Glaucophyta, in spite of the striking similarities with other algae. However, ,,there is some support for a monophyletic origin of plastids, but some analyses indicate polyphyly“ (Howe et al. 2008). My observation is not able to bring any new information in this discussion. It is only confirming the existence of Pascher's genus and species Cryptella cyanophora. Yet, in both cases of glaucophytes observed, the convergence with other algae-Cryptella with Cryptomonas and Glaucocystis with Oocystis - was quite remarkable.

Cryptella cyanophora is according to PASCHER (1929) a colourless flagellate having characteristic shape of cryptomonads: wider apex with slight subapical depression on the cell venter, into which two unegual flagella are inserted. The contractile vacuole is situated within the rounded apex. The antapex is attenuated and contains the rounded nucleus. Pascher observed two parallel rows of tiny ejectosomes running down the cell venter. There was one single bluegreen sphere, probably endocyanelle, approximatly in the middle of the cell. The cells were 14-18 $\mu \mathrm{m}$ long and 8-12 $\mu \mathrm{m}$ wide and thick. NovArino (2003) mentioned that Cryptella is a rare monospecific genus which is known exclusively from Pascher's original observation. So my observation of C. cyanophora (Figs 1-2) is probably the first confirmation of Pascher's genus and species. Nevertheless, the newly described species Cyanophora kugrensii TAKAHASHI et NOZAKI (TAKAHASHI et al. 2014) might be just another observation of Cryptella cyanophora.

Peliaina cyanella PASCHER is similar cryptomo-

Figs 15-21.(15-18) Gymnodinium aeruginosum STEIN: (15a) ventral view, (15b) contour of the equatorial cell level of the same specimen, (16-17) ventral views, (18) lateral view; (19-21) Amphidinium amphidinioides (Geitler) Schiller: (19a) ventral view, (19b) contour of the equatorial cell level of the same specimen, (20-21) ventral views. 


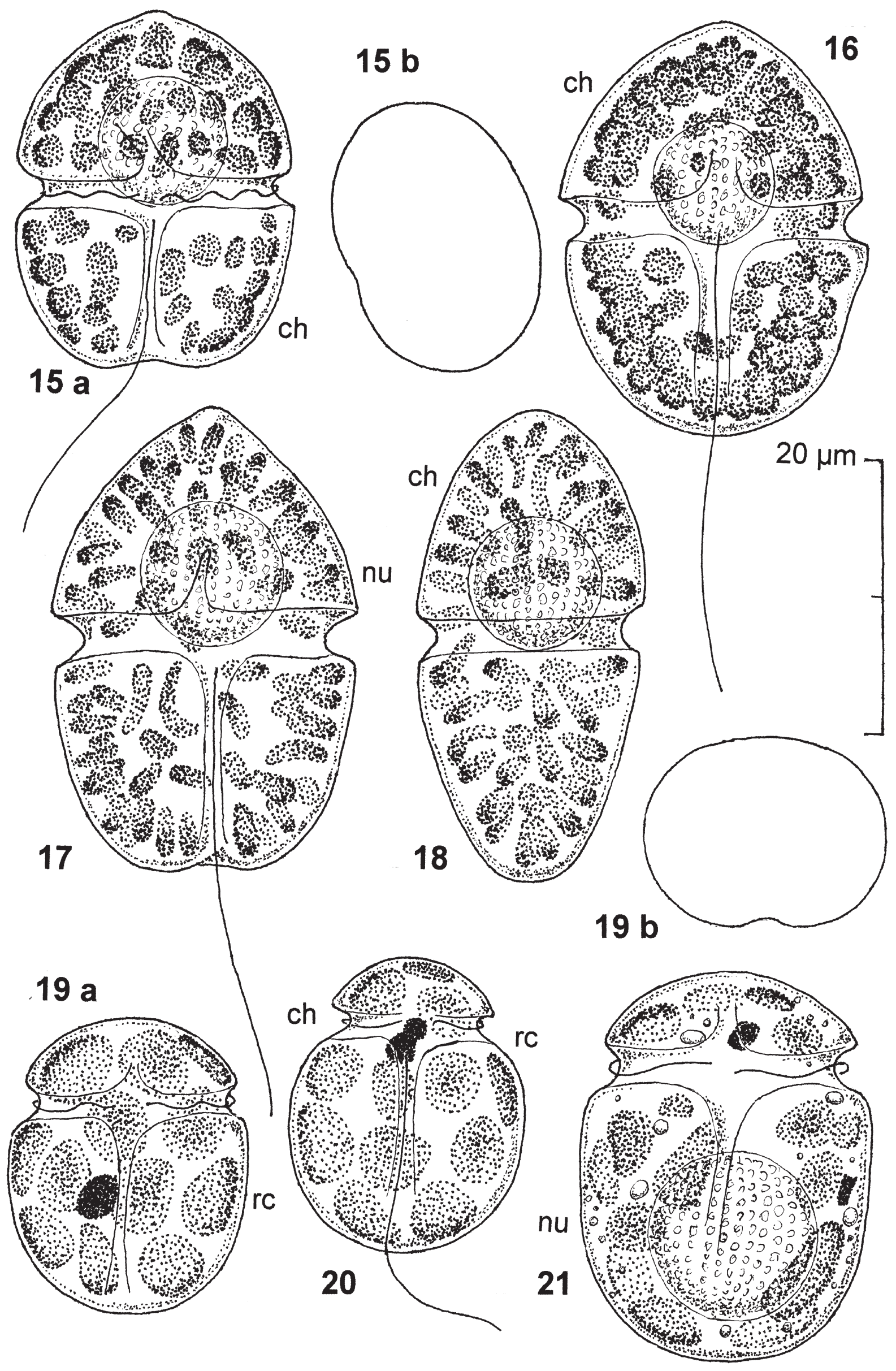


nad-like flagellate, a bit more robust than Cryptella, with cells widely rounded on both ends, 18-27 $\mu \mathrm{m}$ long and 10-13 $\mu \mathrm{m}$ wide and thick. The pair of unequal flagella, apical contractile vacuole and antapical nucleus with nucleolus are similar to the preceding genus. In Peliaina, however, the autor did not observed any ejectosomes. The cells contained several, up to six, spherical cyanelles. The cyanelles and flagellate usually divided simultaneously.

The pictures of the above named species may be found in good compedia of Cryptophyceae, e.g. by STARMACH (1974).

\section{Cryptomonads with blue-green chloroplasts}

There are genera of Cryptophyceae with plastids of clear blue-green coulouring which are certainly not endocyanelles. While Cyanobacteria have only chlorophyll-a, these cryptomonads possess also chlorophyll-c, which is typical for the whole kingdom Chromista proposed and defined by CAVALIER-SMith (1997, 2002).

Chromista are not closely related to the other algae nor to higher plants. In addition to the chlorophylls they carry various other pigments giving them their characteristic brown, golden, red, or blue-green colour. The reserve material of them is not starch. They are the prevailing photosynthetic organisms (along with many heterotroph members) in both marine and freshwater ecosystems. As a matter of fact, the ,kingdom" is just a promotion of the older tribe Chromophyta, which comprised the same algal groups on the level of classes. However Fотт (1971) classified the class Cryptophyceae as ,flagellates of uncertain systematic position".

Moreover the research of the ultrastructure of cryptophycean chloroplasts demonstrated a reduced nucleus, called a nucleomorph. ,This indicates that the plastid was derived from an eukaryotic symbiont, shown by genetic studies to have been a red alga" Rhodophyceae (Douglas et al. 2002). The presence of true pyrenoids in Cryptophyta supports this theory. The primary chloroplasts, originating from prokaryotic endosymbionts (cyanobacteria), are found in most algae and in the higher plants. The secondary, more complex chloroplasts, originating from eukaryotic symbionts, are found e.g. in Chromista. „The origin of primary plastids via endosymbiosis involving a cyanobacterium is well-established, but the origin of secondary plastids is still controversial" (CHAN \& BHATTACHARYA 2010).

Therefore, in spite of the similar cell shape and blue-green colour of plastids, the synonymization of the genus Cryptoglena or Cyanomonas with the genus Chroomonas (HiLl 1991) is not justified.

Taxonomic notes: Chroomonas acuta UTERMÖHL (1925) is most probably the synonymum for $C h$. caudata Geitler (1924). The shape of the cell anta- pex was variable also in my findings. The new generic name and following nomeclatoric combination Komma caudata (GeITLER) Hill (1991) is not valid because Chroomonas caudata has the same ultramicroscopic structure of periplast compound with hexagonal plates as the type species of the genus, Chroomonas nordstedtii (Novarino \& Oliva 1998).

\section{Dinoflagellates with blue-green chloroplasts}

Also in another class of Chromophyta (Chromista), in Dinophyceae, there are some species with bright blue-green chloplasts. Fотт (1971) wrote: „Die blauen Chromatophoren, die bei Dinoflagellaten (Gymnodinium aeruginosum) gefunden wurden, sind wahrscheinlich Cyanellen (symbiotische Cyanophyceen)“. Popovský \& Pfiester (1990) admit this possible origin of chloroplasts in Amphidinium amphidinioides. Later research, however, demonstrated that the evolution of blue-green plastids in Dinophyceae is more complicated. ScHNEPF et al. (1989) published about G. aeruginosum: ,Recent research has revealed that the blue-green colour of 'chromatophores' does not necessarily imply that they are cyanelles, i.e. that they have directly descended from cyanobacteria, procaryotes. This may also be the result of an endocytobiotic association with a cryptomonad, i. e. with a phycobiline-containing eucaryote". They mention that the cell of this dinoflagelate houses an endosymbiont with typical blue-green cryptophycean chloroplasts, cryptophycean starch grains, and the cryptophycean cytoplasm which contains mitochondria, vesicles and ribosomes, but no eukaryotic nucleus. The endosymbiont is surrounded by a single membrane.

\section{Glaucocystis nostochinearum ITZIGSOHN (1854)}

The structure of cells and colonies of Glaucocystis is similar if not identical with the chlorococcal alga $\mathrm{Oo}^{-}$ cystis, having, however, cyanelles instead of chloroplasts. Nevertheless, the contractile vacuoles were observed in young autospores (KoRSHIKOv 1953), as well as rudiments of flagella (SCHNEPF et al. 1966). Therefore the affinity of Glaucocystis to coccal green algae is not sure, and the above mentioned discoveries call attention to tetrasporal green algae (Fотт 1971).

Figs 22-25. Glaucocystis nostochinearum Itzigsohn: $(22,25)$ free living vegative cells, $(23,24)$ colonies of autospores inside the mother cell wall.

$\overrightarrow{\text { Figs 26-29. Glaucocystis nostochinearum ITzIGSOHN: (26) vegetative }}$ cell clung to the filament of Oedogonium, having two sets of cyanelles, $(27,28)$ free living vegative cells, $(29)$ colony of autospores inside the mother cell wall.

Figs 30-32. Glaucocystis nostochinearum ITZIGSOHN: (30) colony with cracking mother cell wall before releasing the autospores, (31) free living vegative cell, (32) colony of only two autospores; the mother cell wall has thickening only on one pole. 


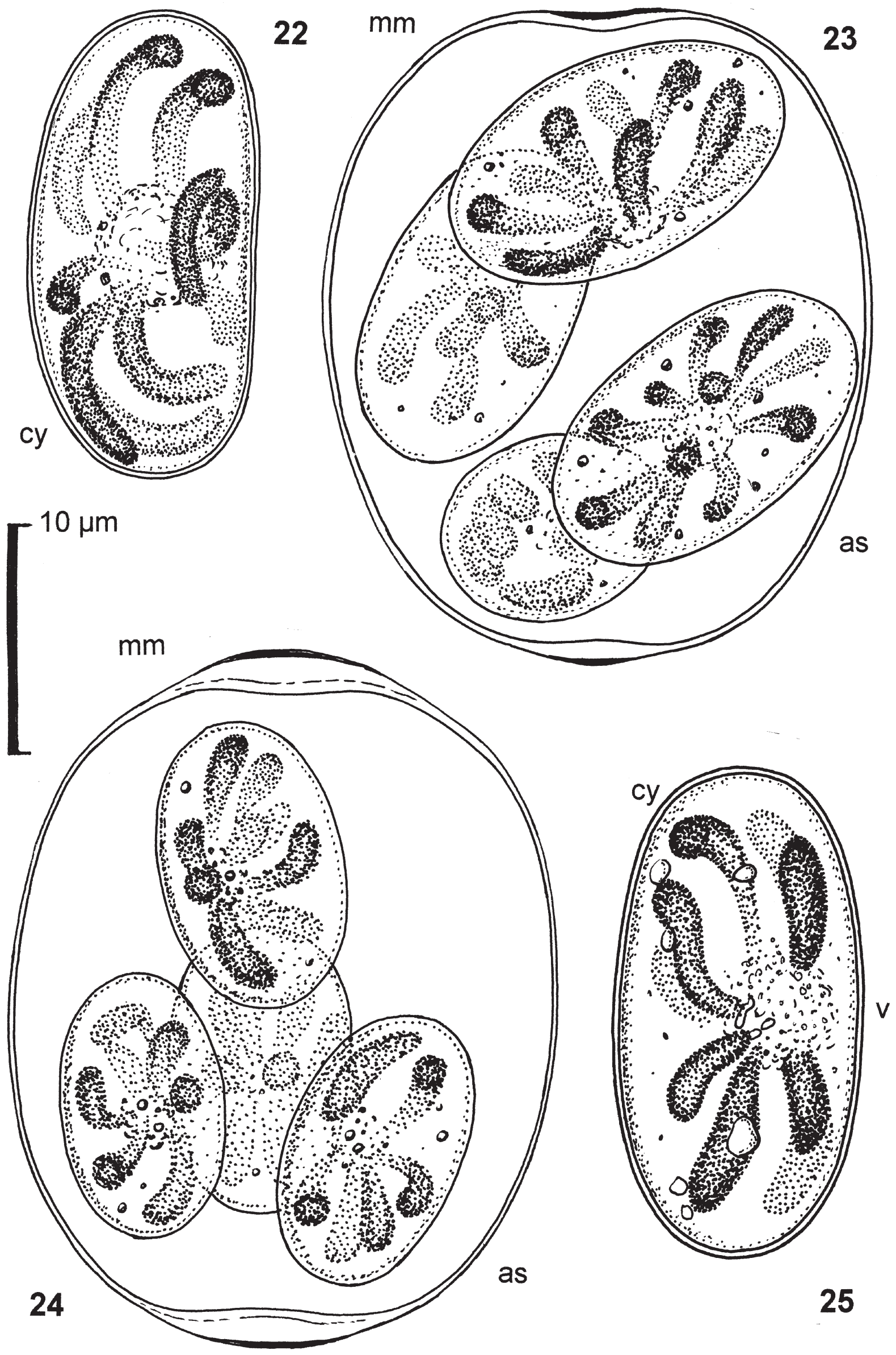




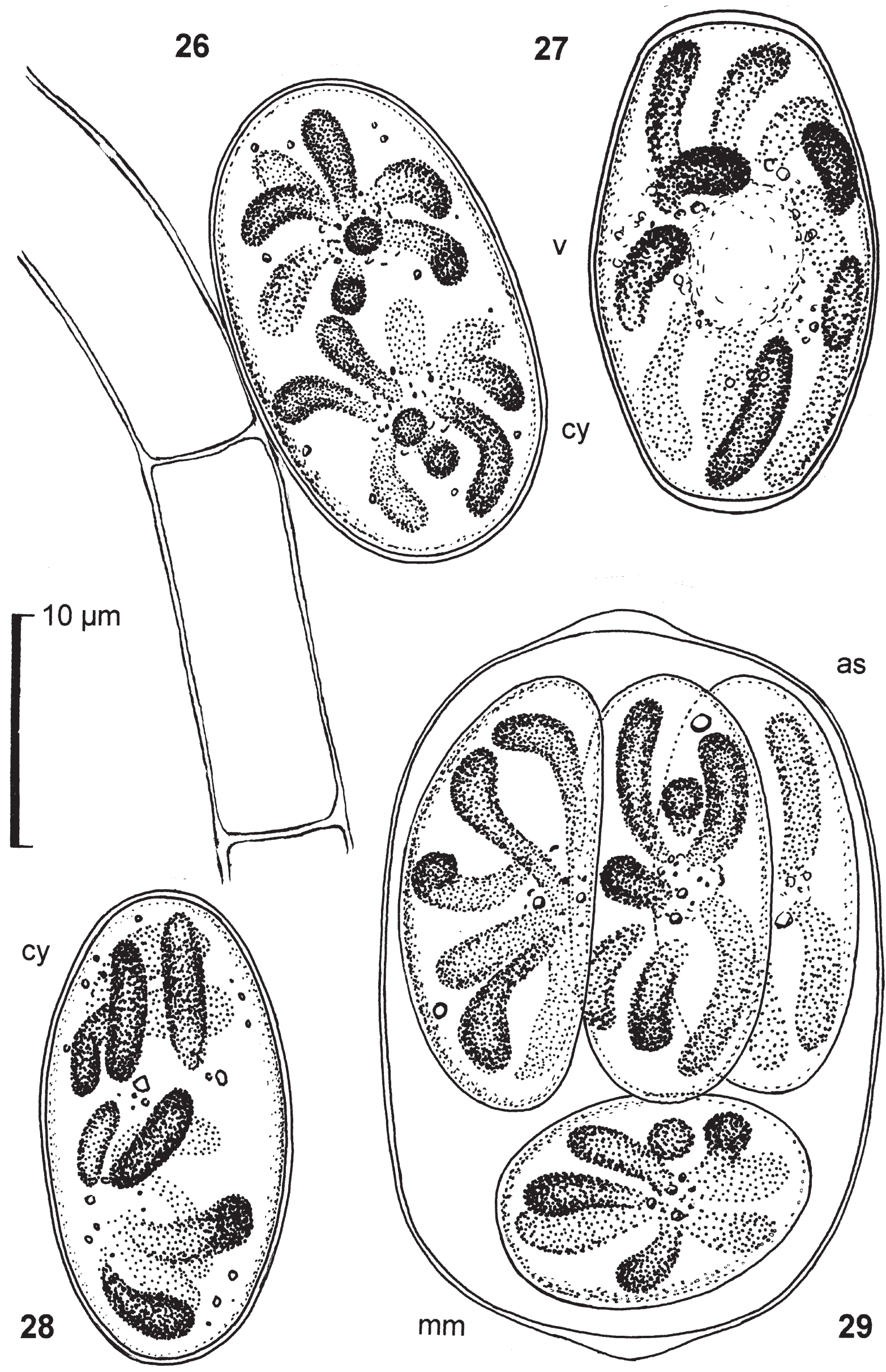




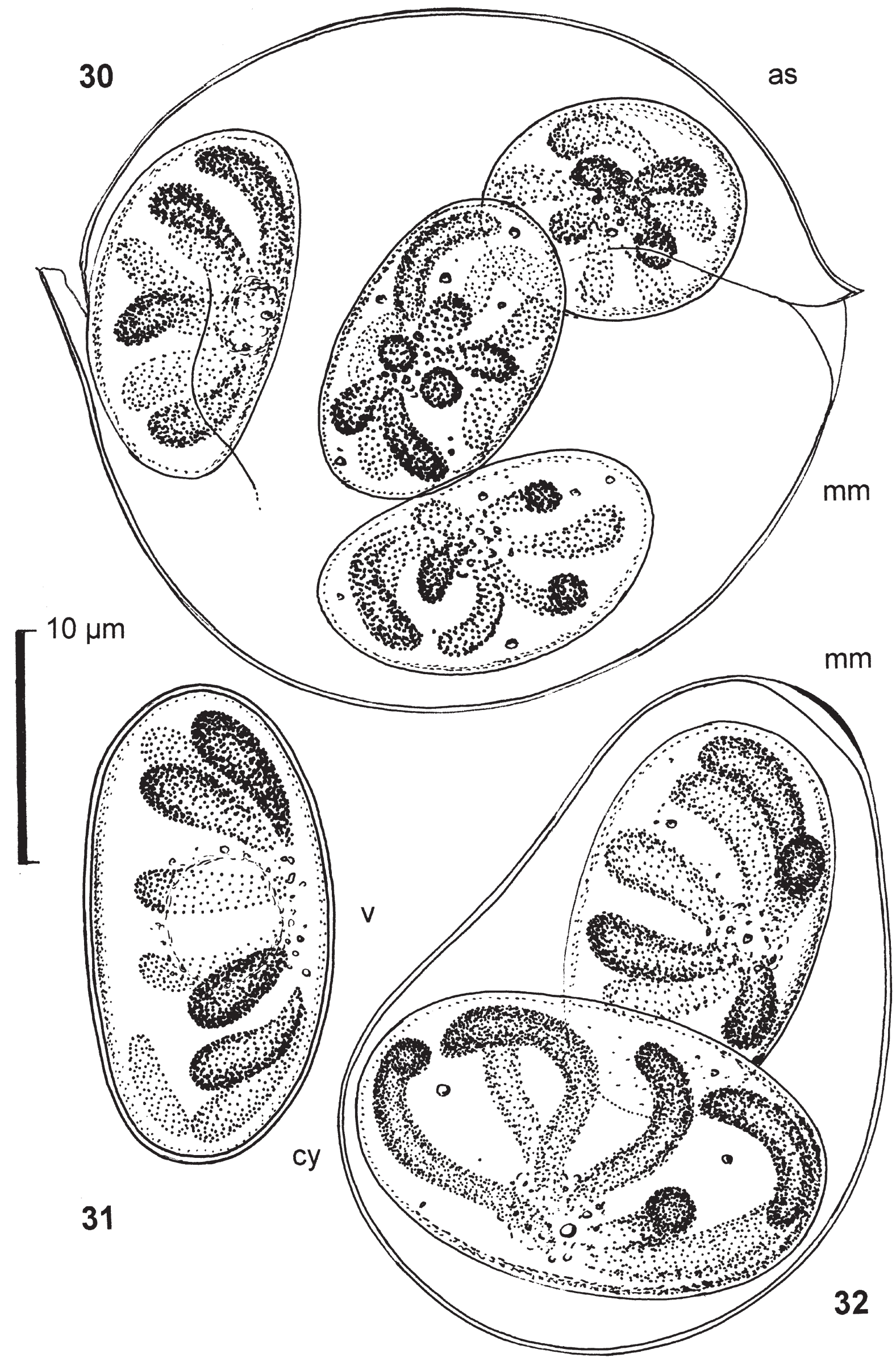


Several species have been described but their real existence should be ascertained. G. oocystiformis PRESCOTT differs from the type species by ,numerous chromatophores, irregular pads at the periphery of the cell" and by „nodular thickenings of the cell wall at the poles“ (Prescott 1951). Prescott himself is quoting HieronyMUs (1892) who found the similar discoid cyanelles to be the developmental stages in $G$. nostochinearum. On the contrary, KoRSHIKOv (1953) describes the ,biscuitshape blue-green chromatophores" as the only type he observed in G. nostochienarum. Another species G. duplex PRESCOTT, is characterized by two sets of cyanelles in each cell which could be the development stage of G. nostochinearum. Nevertheless, this Prescott's species is unusually large and has spherical cells.

\section{REFERENCES}

CAVAlieR-Smith, T. (1997): Sagenista and Bigyra, two phyla of heterotrophic heterocont Chromists. - Archiv f. Protistenkunde 148: 253-267.

CAVAlier-Smith, T. (2002): The phagotrophic origin of eukaryotes and phylogenetic classification of Protozoa. Internat. - Jour. System. Evolution. Mikrobiology 52: 297-354.

Chan, C. X. \& Bhattacharya, D. (2010): The Origin of Plastids. Nature Education 3: 84-91.

DAvis, B.M. (1894): Notes on the life-history of a blue-green motile cell. Bot. - Gazette 19: 96-102.

Douglas, S.; Zauner, S.; Fraunholz, M.; Beaton, M.; Penny, S.; Deng, L.T.; Wu, X.; Reith, M.; Cavalier-Smith, T. \& MAIER, U.G. (2002): The highly reduced genome of an enslaved algal nucleus. - Nature 410: 1091-1096.

FogG, G. E.; SteWARt, W. D. P.; FAy, P. \& Walsby, A.E. (1973): The Blue-Green Algae, chapt. 17 Symbiosis. - pp. 353-356, Academic Press, London.

Hieronymus, G. (1892): Beiträge zur Morphologie and Biologie der Algen I: Glaucocystis Nostochinearum Itzigsohn. - Beitr. Biol. Pflanzen 5: 461 - 495.

HiLl, D.R.A. (1991): Chroomonas and other blue-green cryptomonads. - J. Phycol. 27: 133 - 145

Hoffmann, L. \& Kostikov, I. (2004): New record of Glaucocystis nostochinearum (Glaucophyta) in Belgium. - Belg. Journ. Botan. 137: 205-208.

Howe, C. J.; Barbrook, A.C.; Nisbet, R.E.R.; Lockhart, P.J. \& LarKUM, A.W.D. (2008): The origin of plastids. - Phil.Trans.R. Soc. B 363: 2675-2685.

Huber-Pestalozzi, G. (1950): Das Phytoplankton des Süsswassers. Systematik und

Biologie 3. Cryptophyceen, Chloromonadinen, Peridineen. - In Thienemann, A. (ed.): Die Binnengewässer 16/ 3. - 310 pp., Schweitzerbart'she Verlagsbuchhandlung, Stuttgart.

JAVORNICKÝ, P. (1978): Trieda Cryptophyceae - kryptomonády. - In F. Hindák (ed.): Sladkovodné riasy (Freshwater Algae). pp. 451-465, SPN, Bratislava.

JavornickÝ, P. \& Popovský, J. (1978): Trieda Dinophyceae - panciernatky. - In: HindÁK, F. (ed.): Sladkovodné riasy (Freshwater Algae). - pp. 420-451, SPN, Bratislava.

Kiselev, I. A. (1954): Pirofitovye vodorosli. - In: Gollerbach, PolJANSKIJ \& SAVIČ (eds): Opredelitel presnovodnych vodoroslej SSSR 6: 1-212.

KorshiKov, O. A. (1924): Protistologische Beobachtungen I. Cyanophora paradoxa $\mathrm{n}$. g. et sp. - Russ. Archiv Protistology 3: 57-74.

KorshiKov, O. A. (1953): Pidklas Protokokovi (Protococcineae). In: Roll, J.V.; OKSner, A.M. \& TONatcheVkiJ, O.V. (eds): Viznačnik prisnovodnich vodorostej Ukrainskoi RSR 5:
$1-437$.

LEE, R.E. (2008): Phycology (4th ed.). - 560 pp., Cambridge University Press, Cambridge.

Martin, W. \& Kowallik, K.V. (1999): Annotated English translation of Mereschkowsky's 1905 paper „Über Natur und Ursprung der Chromatophoren im Pflanzenreiche. - Eur. J. Phycol. 34: $287-295$.

Mereschkowski, C. (1905): Über Natur und Ursprung der Chromatophoren im Pflanzenreiche. - Biol. Centralblatt 25: 593-604.

Müller, N. E.; Hauler, O. \& Schenk, H. E. A. (1997): The Phycobiliproteins within the Cyanoplast of Cyanophora paradoxa Store Carbon, Nitrogen, and Sulfur for the Whole Cell. In: Schenk, H.E.A.; Herrmann, R.G.; Jeon, K.W.; Müller, N.E. \& Schwemmler, W. (eds): Eukaryotism and Symbiosis. - pp. 252-260, Spriger Verlag, Berlin, Heidelberg.

Novarino, G. (2003): A companion to the identification of cryptomonad flagellates (Cryptophyceae $=$ Cryptomonadea).- In: Naselli-Flores, L.; Padisák, J.; \& Dokulil, M.T. (eds): Hydrobiologia 502: $225-270$.

Oltmanns, F. (1904): Morfologie und Biologie der Algen I. - 733 pp., Gustaf Fischer Verlag, Jena.

Pascher, A. (1913): Cryptomonadineae. - In: Pascher, A. (ed.): Süsswasserfl. Deutschl. Österr. und der Schweiz, Vol. 2. - pp. 97-114, Verlag von Gustav Fischer, Jena.

Pascher, A. (1929): Sudien über Symbiosen I. Über einige Endosymbiosen von Blaualgen in Einzellern. - Jahrbücher für wissenschaftliche Botanik 71: 386-462.

Playfair, G. J. (1921): Australan Freshwater Flagellates. - Proc. Linn. Soc. N. S. Wales 46: 99-146.

Prescott, G.W. (1951) Algae of the western Great Lakes area. Cranbrook Institute of Science, Bulletin 31: 1-946.

Schnepf, E.; Winter, S. \& Mollenhauer, D. (1989): Gymnodinium aeruginosum (Dinophyta): a blue-green dinoflagellate with a vestigial, anucleate, cryptophycean endosymbiont. - Plant Systematic and Evolution 164: 75 - 91.

SkujA, H. (1948): Taxonomie des Phytoplanktons einiger Seen in Uppland, Schweden. - Symbolae Botanicae Upsalienses IX, 3: 1-399.

Skuja, H. (1954): Glaucophyta. - In: Melchior, H. \& Werdermann, E. (eds): A. Engler's Syllabus der Pflanzenfamilien: mit besonderer Berücksichtigung der Nutzpflanzen nebst einer Übersicht über die Florenreiche und Florengebiete der Erde, I Band Allgemeiner Teil Bakterien bis Gymnospermen, $12^{\text {th }}$ ed. - pp. 56-57, Gebrüder Borntaeger, Berlin.

Takahashi, T., M. Sato, K. Toyooka, R. Matsuzaki, K. Kawafune, M. Kawamura, Okuda, K. \& Nozaki, H. (2014): Five Cyanophora (Cyanophorales, Glaucophyta) species delineated based on morphological and molecular data. - J. Phycol. 50:1058-1069.

UtermöHL, H. (1925): Limnologische Phytoplanktonstudien. - Arch. Hydrobiol., Suppl. 5: 1-527.

(C) Czech Phycological Society (2016)

Received June 15, 2015

Accepted November 10, 2015 